\title{
Tax incentives for small business as a factor of sustainable development of the region in Russia
}

\author{
Karen Tumanyants \\ Volgograd State University \\ Institute of Economics and Finance \\ Department of Economic Theory, world and regional \\ economies \\ Volgograd, Russia \\ tumanjancka@volsu.ru
}

\author{
Evgenia Gulyaeva \\ Volgograd Institute of Management - branch of \\ Russian Presidential Academy of National Economy \\ and Public Administration \\ Department of Linguistics and Intercultural \\ Communication \\ Volgograd, Russia \\ guevgenia@yandex.ru
}

\begin{abstract}
The article considers possibility of ensuring positive dynamics of territorial development through arrangement of favorable tax conditions for business activities. The authors give a quantitative estimate of reaction of the Russian small enterprises to reduction of a tax rate. By the aid of the ordinary least squares technique and the fixed effects model, the analysis of results of small business activitiy for 2006-2015 period in all regions of the Russian Federation has been carried out. The dependence established between the amount of the tax charged within the simplified tax system and the size of the tax rate on "net income" in the region is described by quadratic function with minus coefficient a. The value of the mentioned rate on average in the regions of the Russian Federation for the considered period was at the level above optimum. Tax rate decrease by regional authorities as well as its differentiation for small enterprises and individual entrepreneurs will encourage increase in range of legal activity of small businesses in Russia. The conclusion is made about expediency of use of tax methods to support small businesses for activization of development of regional economy and achievement of stable rates of its growth.
\end{abstract}

Keywords - tax rate, small business, tax income, incentive, fixed effects model, ordinary least squares technique, region

\section{INTRODUCTION}

Competitive small business is considered as one of important factors of dynamic development of any territory. Flexibility and mobility of small forms of economic activity provide a variety of goods and services supply, improve equation of labor market, raise tax revenues to local budgets, and improve economic resilience and social life stability of the region. Thanks to the mentioned properties, the territories, where small business plays a noticeable role, react better to arising socio-political and economic challenges.

These circumstances determine the fact that in the majority of the countries the state assumes special measures for small business support. Increase in significance of small business for the Russian Federation is an especially critical task. For the last years both federal and regional authorities constantly fulfill the programs of small business encouragement. Nevertheless in the prevailing part of the territorial subjects of the Russian Federation large enterprises still dominate in occupational pattern and output mix.

One of the most important positions in the system of the governmental instruments of small business support belongs to the taxation. Theoretically, tax burden decrease must give a positive impulse to business development. Establishing reduced tax rates, providing exemptions on a taxation object and a delay on tax payments, the government creates more comfortable tax conditions for small companies and their economic activity in comparison with larger enterprises. The effect of reduced tax rates includes both motivation to increase in output thanks to economy on the amount of tax liabilities and to increase in net margin, and an incentive for redistribution of proportions between legal and shadow parts of economy in favor of the former thanks to reduction of comparative costs.

However, the empirical estimators of the influence of different component parts of taxation on economic activity have a contradictory character. Besides, the results of testing the hypothesis about a positive impact of liberal tax regime on the company's business can't be universal. The size of the tax burden for different countries and time periods will vary significantly.

The aim of this research is to reveal interrelation between the tax rate and the dynamics of development of legal small businesses in the region. Taking into consideration the inhomogeneity of micro-entrepreneurship, the authors entrust themselves with a task to describe the peculiarities of tax rate influence on the performance results of small enterprises (SE) and individual entrepreneurs (IE). Taking into account budget deficit and material debt of most Russian regions, the research was oriented on determining the optimized level of small business taxation that will make it possible to maximize tax basis, and, consequently, a total of tax revenues by means of economic activity growth. 


\section{MATERIALS AND Methods (MODEL)}

The research methodology is based on the model of the relationship between the tax rate and the tax revenue which is known as the Laffer curve. For the first time, this approach was described not in the work of its author, but in the article [1] of his interlocutor at dinner, where on a napkin A. Laffer drew a graph that later became canonical. Describing his theory later [2], A. Laffer himself noted the presence of two effects of changes in tax rates on budget revenues: arithmetic and economic. With the latter he connected the impact of low taxes on the growth of the taxation base. For fairness sake it should be noted that long before A. Laffer the idea of a possible increase in tax revenues in response to tax reduction was expressed by J. M. Keynes [3, p. 7]: «Nor should the argument seem strange that taxation may be so high as to defeat its object, and that, given sufficient time to gather the fruits, a reduction of taxation will run a better chance than an increase of balancing the budget. ».

Despite evident logic and correspondence to common sense, the empirical testing of the Laffer curve equity gives contradictory results. After econometric model building of the data of the OECD member countries for the period from 1980 to 2004, Slemrod J., \& Kawano L. [4] noted a weak relationship between a tax rate and tax payments. In their model the dependent variable was presented by the ratio of corporate taxes to gross domestic product (GDP), and the tax rate and its square were the explanatory variables. In addition, the specification of the equation included control variables GDP growth rates, logarithm of GDP per capita and some other dimensions. The coefficient estimation was performed with the aid of the ordinary least squares method (OLS) and the model of fixed effects (MFE).

Using a quadratic equation to estimate the influence of a tax rate on tax revenues for 20 OECD member countries from 1965 to 2004, M. Devereux [5] obtained contradictory results. He concludes that if there is a relationship between the rate and the tax revenue, it is extremely weak. The positive effect and maximization of tax revenues occur only at very low tax rates.

At the same time, K. Clausing [6] confirmed the existence of parabolic (hereinafter we mean that the value of the tax rate is reflected on the horizontal axis, and the value of tax payments is reflected on the vertical axis, the parabola branches are directed downwards) relation between the tax rate and tax revenues for the period from 1979 to 2002 in the OECD member countries. According to his calculations, tax revenues from business reach their maximum value at a rate of $33 \%$. In a study by Brill A. \& Hassett K. [7] the use of the quadratic function to describe the interrelation between the tax rate and the amount of taxes from 1980 to 2005 in OECD countries also yielded positive results.

Thus, the basic specification of the model used in the study can be represented as follows:

$$
y=a x^{2}+b x+c, \text { where }
$$

- $y-$ the amount of taxes in absolute terms or relative to GDP;
- $\mathrm{x}$ - the size of the tax rate;

- $\mathrm{c}$-control variables.

Since 2009 the regions of the Russian Federation have obtained the right to set by themselves a tax rate on the object "income minus expenses" (net income) for taxpayers using the simplified tax system (STS). Up to and including 2008 the rate of this tax was $15 \%$, and then in the Tax Code of the Russian Federation only its minimal (5\%) and maximum (15\%) values were defined.

The horizon period of the study includes the period from 2006 to 2015, during which the first three years in all regions there was a single rate. During the next 7 years the size of the rate was differentiated in the subjects of the Russian Federation, and in some regions it was repeatedly changed.

The information base of the study was presented by the data of the Federal Tax Service about the amount of the taxes charged and paid within the STS for each subject of the Russian Federation. The control variables were the data of the Federal State Statistics Service about the size of gross regional product (GRP) in absolute and per capita terms. In addition, the value of investment potential determined annually for each subject of the Russian Federation by the Rating Agency "Expert" within the framework of the project "Rating of investment attractiveness of Russian regions" was used as a control variable. Descriptive statistics of the data file comprising 830 observations is presented in Table I.

TABLE I. DESCRIPTIVE STATISTICS

\begin{tabular}{|c|c|c|c|c|c|}
\hline Variable & Symbol & Mean & $\begin{array}{c}\text { Std. } \\
\text { Dev. }\end{array}$ & $\begin{array}{c}\text { Minim } \\
\text { um }\end{array}$ & $\begin{array}{c}\text { Maxim } \\
\text { um }\end{array}$ \\
\hline Tax & TaxAll & 2346.3 & 5050.8 & 19.2 & 74700.2 \\
\hline Tax of SE & TaxEnt & 1522.3 & 3253.1 & 17.4 & 41118.8 \\
\hline Tax of IE & TaxIp & 824.0 & 1866.0 & 1.8 & 33581.4 \\
\hline $\begin{array}{c}\text { Tax to } \\
\text { GRP }\end{array}$ & TaxAllInGRP & 0.5 & 0.3 & 0.0 & 3.1 \\
\hline $\begin{array}{c}\text { Tax of SE } \\
\text { to GRP }\end{array}$ & TaxEntInGRP & 0.3 & 0.2 & 0.0 & 1.5 \\
\hline $\begin{array}{c}\text { Tax of IE } \\
\text { to GRP }\end{array}$ & TaxIpInGRP & 0.2 & 0.1 & 0.0 & 0.8 \\
\hline \begin{tabular}{c} 
Tax rate \\
\hline GRP
\end{tabular} & TaxRate & 13.4 & 2.7 & 5.00 & 15.00 \\
\hline $\begin{array}{c}\text { GRP per } \\
\text { capita }\end{array}$ & GRPperCap & 310.3 & 470.1 & 21.9 & 4990.3 \\
\hline Potential & Poten & 42.1 & 24.1 & 1.0 & 85.0 \\
\hline
\end{tabular}

Considering the fact that the Russian tax legislation allows the taxpayers using the STS to change the object of taxation once a year, choosing between gross income (gross yield) and net income, we took into account all the tax liabilities within the STS. This approach makes it possible to exclude distortion of the overall estimates due to changing one tax regime to another by taxpayers, although the reverse side is a decrease in accuracy of calculations.. 


\section{RESULTS AND DISCUSSION}

Having evaluated the quality of models when using linear, double logarithmic, linear-logarithmic and logarithmic - linear equations in specification (1), the authors stopped at the lastmentioned one. It was characterized by higher values of the coefficient of determination and the lowest values of the Akaike and Schwartz information criteria. As a result, the econometric model used in the study took the following form:

$$
\begin{array}{r}
\ln Y_{i}=b_{0}+{ }_{1} \text { TaxRate }_{i}{ }^{2}+{ }_{2} \text { TaxRate }_{i}+{ }_{3} \text { GRP }_{i}+{ }_{4} \text { GRPperCap }_{i}+ \\
+{ }_{6} \text { Poten }_{i} \text {, where }
\end{array}
$$

$\mathrm{Y}$ - the tax amount in absolute terms or relative to GRP in the $\mathrm{i}$ region of the Russian Federation.

To accomplish the tasks set in the study, in the equation (2) the amount of taxes for all payers using the STS in total as well as separately for SE and IE was used as a dependent variable. In addition, as in the work of Brill A. \& Hassett K. [7], the calculations were carried out in two versions: with account of the annual time lag and without it. The comparison of the values of the coefficients of determination and the information criteria for each model gives evidence of higher quality of the equations evaluated with account of the fixed effects.

\section{A. Results for all taxpayers using the STS}

We have found a statistically significant relationship between the sum of accrued taxes and the value of the tax rate on net income in the region (Table II). Although in the regression for TaxAllInGRP the significance of the coefficients with the TaxRate 2 and TaxRate variables is statistically confirmed, it is not included in the table, because (as it will be shown below) the revealed effect for this dependent variable is explained only by the reaction of the individual entrepreneur to the change in the tax rate.

The negative value of the $\beta 1$ coefficient indicates that as the tax rate increases, the amount of accrued taxes increases first and then begins to fall. Practically complete coincidence of the results in estimating by the OLS and within the framework of MFE counts in favor of reliability of the data obtained. The effect appears in the year of the rate change and is preserved with a slightly weakened force the next year.

TABLE II. ESTIMATED COEFFICIENTS OF THE MODELS FOR ALL TAXPAYERS USING THE STS

\begin{tabular}{|c|c|c|c|c|}
\hline \multirow{2}{*}{$\begin{array}{c}\text { Independent } \\
\text { variables }\end{array}$} & \multicolumn{4}{|c|}{ Dependent variable: TaxAll } \\
\cline { 2 - 5 } & \multicolumn{2}{|c|}{ No time lag } & \multicolumn{1}{c|}{ 1 year time lag } \\
\cline { 2 - 5 } & $\boldsymbol{O L S}$ & $\boldsymbol{M F E}$ & $\boldsymbol{O L S}$ & $\boldsymbol{M F E}$ \\
\hline \multirow{2}{*}{ TaxRate } & $-0.02^{* * *}$ & $-0.02^{* * *}$ & $-0.02^{* * *}$ & $-0.02^{* * *}$ \\
& $(0.01)$ & $(0.01)$ & $(0.01)$ & $(0.01)$ \\
\hline \multirow{2}{*}{ TaxRate } & $0.52^{* * * *}$ & $0.37^{* * *}$ & $0.50^{* * *}$ & $0.33^{* * *}$ \\
& $(0.20)$ & $(0.07)$ & $(0.20)$ & $(0.05)$ \\
\hline \multirow{2}{*}{ GRP } & $0.01^{* * * *}$ & $0.01^{* *}$ & $0.01^{* * *}$ & $0.01^{* *}$ \\
& $\left(3.9 \times 10^{-5}\right)$ & $(0.01)$ & $\left(3.3 \times 10^{-5}\right)$ & $(0.01)$ \\
\hline \multirow{2}{*}{ GRPperCap } & -0.01 & $0.01^{* *}$ & $-0.01^{* *}$ & $0.01^{* *}$ \\
& $(0.01)$ & $(0.01)$ & $(0.01)$ & $(0.01)$ \\
\hline \multirow{2}{*}{ Poten } & $-0,03^{* * *}$ & 0.01 & $-0.03^{* * * *}$ & 0.01 \\
& $(0.01)$ & $(0.01)$ & $(0.01)$ & $(0.01)$ \\
\hline \multirow{2}{*}{ const } & $5.93^{* * *}$ & $5.26^{* * *}$ & $6.12^{* * *}$ & $5.64^{* * *}$ \\
& $(0.82)$ & $(0.48)$ & $(0.83)$ & $(0.34)$ \\
\hline
\end{tabular}

\begin{tabular}{|c|c|c|c|c|}
\hline \multirow{2}{*}{$\begin{array}{c}\text { Independent } \\
\text { variables }\end{array}$} & \multicolumn{4}{|c|}{ Dependent variable: TaxAll } \\
\cline { 2 - 5 } & No time lag & 1 year time lag \\
\cline { 2 - 5 } & OLS & MFE & OLS & MFE \\
\hline $\mathrm{R}^{2}$ & 0.68 & 0.94 & 0.71 & 0.96 \\
\hline Akaike & 1730.5 & 541.9 & 1450.2 & 79.8 \\
\hline \multicolumn{4}{|c}{} & ${ }^{*} \mathrm{p}<0.1$ \\
${ }^{* *} \mathrm{p}<0.05$ \\
${ }^{* * *} \mathrm{p}<0.01$
\end{tabular}

\section{B. Results for the SE using the STS}

For the taxpayers - legal entities the patterns mentioned above are also observed (Table III). However, the degree of sensitivity of SE to changes in the tax rate is lower than for all small businesses in general using the STS. This fact is proved by the lower derivative value for all four model variants. In addition, the absence of the importance of the $\beta 1$ and $\beta 2$ coefficients in the equation with the dependent variable characterizing the amount of taxes as a percentage of GRP also indirectly indicates smaller dependence of the results of legal activities of the SE on the level of the tax rate.

TABLE III. ESTIMATED COEFFICIENTS OF THE MODELS FOR SE USING THE STS

\begin{tabular}{|c|c|c|c|c|}
\hline \multirow{2}{*}{$\begin{array}{c}\text { Independent } \\
\text { variables }\end{array}$} & \multicolumn{4}{|c|}{ Dependent variable: TaxEnt } \\
\cline { 2 - 5 } & \multicolumn{2}{|c|}{ No time lag } & 1 year time lag \\
\cline { 2 - 5 } & OLS & MFE & OLS & MFE \\
\hline \multirow{2}{*}{ TaxRate ${ }^{2}$} & $\begin{array}{c}-0.02^{* * *} \\
(0.01)\end{array}$ & $\begin{array}{c}-0.02^{* * *} \\
(0.01)\end{array}$ & $\begin{array}{c}-0.02^{* * *} \\
(0.01)\end{array}$ & $\begin{array}{c}-0.02^{* * *} \\
(0.01)\end{array}$ \\
\hline \multirow{2}{*}{ TaxRate } & $\begin{array}{c}0.45^{* * *} \\
(0.16)\end{array}$ & $\begin{array}{c}0.35^{* * *} \\
(0.06)\end{array}$ & $\begin{array}{c}0.43^{* * *} \\
(0.15)\end{array}$ & $\begin{array}{c}0.31^{* * *} \\
(0.04)\end{array}$ \\
\hline \multirow{2}{*}{ GRP } & $\begin{array}{c}0.01^{* * *} \\
\left(3.6 \times 10^{-5}\right)\end{array}$ & $\begin{array}{c}0.01^{* *} \\
(0.01)\end{array}$ & $\begin{array}{c}0.01^{* * *} \\
\left(3.1 \times 10^{-5}\right)\end{array}$ & $\begin{array}{c}0.01^{* *} \\
(0.01)\end{array}$ \\
\hline \multirow{2}{*}{ GRPperCap } & $\begin{array}{c}-0.01^{* *} \\
(0.01)\end{array}$ & $\begin{array}{c}0.01^{* * *} \\
(0.01)\end{array}$ & $\begin{array}{c}-0.01^{* * *} \\
(0.01)\end{array}$ & $\begin{array}{c}0.01^{* *} \\
(0.01)\end{array}$ \\
\hline \multirow{2}{*}{ Poten } & $\begin{array}{c}-0,04^{* * *} \\
(0.01)\end{array}$ & $\begin{array}{c}-5.59 \times 10^{-6} \\
(0.01)\end{array}$ & $\begin{array}{c}-0.03^{* * *} \\
(0.01)\end{array}$ & $\begin{array}{c}0.01 \\
(0.01)\end{array}$ \\
\hline \multirow{2}{*}{ const } & $\begin{array}{c}5.83^{* * *} \\
(0.81)\end{array}$ & $\begin{array}{c}4.90^{* * *} \\
(0.38)\end{array}$ & $\begin{array}{c}6.01^{* * *} \\
(0.80)\end{array}$ & $\begin{array}{c}5.26^{* * *} \\
(0.28)\end{array}$ \\
\hline \multirow{2}{*}{$\mathrm{R}^{2}$} & 0.72 & 0.95 & 0.75 & 0.97 \\
\hline Akaike & 1600.9 & 386.7 & 1330.2 & -66.8 \\
\hline
\end{tabular}

\section{Results for the IE using the STS}

According to the results of econometric model building physical persons engaged in entrepreneurial activities without company formation are the most sensitive to changes in the tax rate on "net income" (Table IV). In all other respects the above-mentioned interrelations between the range of legal activity and the size of the tax rate are also common to them. 
TABLE IV. ESTIMATED COEFFICIENTS OF THE MODELS FOR IE USING THE STS

\begin{tabular}{|c|c|c|c|c|}
\hline \multirow{3}{*}{$\begin{array}{c}\text { Independent } \\
\text { variables }\end{array}$} & \multicolumn{4}{|c|}{ Dependent variable: TaxIp } \\
\hline & \multicolumn{2}{|c|}{ No time lag } & \multicolumn{2}{|c|}{1 year time lag } \\
\hline & $O L S$ & MFE & OLS & MFE \\
\hline TaxRate $^{2}$ & $\begin{array}{c}-0.03^{* * * *} \\
(0.01)\end{array}$ & $\begin{array}{c}-0.02^{* * * *} \\
(0.01)\end{array}$ & $\begin{array}{c}-0.02^{* * * *} \\
(0.01)\end{array}$ & $\begin{array}{c}-0.02^{* * *} \\
(0.01)\end{array}$ \\
\hline TaxRate & $\begin{array}{l}0.53^{* * * *} \\
(0.15)\end{array}$ & $\begin{array}{l}0.39^{* * *} \\
(0.10)\end{array}$ & $\begin{array}{l}0.51^{* * * *} \\
(0.15)\end{array}$ & $\begin{array}{c}0.37^{* * * *} \\
(0.07)\end{array}$ \\
\hline GRP & $\begin{array}{c}0.01^{* * *} \\
\left(4.3 \times 10^{-5}\right)\end{array}$ & $\begin{array}{l}0.01^{* *} \\
(0.01)\end{array}$ & $\begin{array}{c}0.01^{* * *} \\
\left(3.6 \times 10^{-5}\right)\end{array}$ & $\begin{array}{l}0.01^{* *} \\
(0.01)\end{array}$ \\
\hline GRPperCap & $\begin{array}{c}-6.6 \times 10^{-5} \\
(0.01)\end{array}$ & $\begin{array}{l}0.01^{* *} \\
(0.01)\end{array}$ & $\begin{array}{l}-0.01 \\
(0.01)\end{array}$ & $\begin{array}{l}0.01^{*} \\
(0.01)\end{array}$ \\
\hline Poten & $\begin{array}{c}-0,03^{* * * *} \\
(0.01)\end{array}$ & $\begin{array}{l}-0.01 \\
(0.01)\end{array}$ & $\begin{array}{c}-0.04^{* * *} \\
(0.01)\end{array}$ & $\begin{array}{l}-0.01 \\
(0.01)\end{array}$ \\
\hline const & 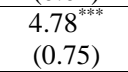 & $\begin{array}{l}4.25^{* * *} \\
(0.71)\end{array}$ & $\begin{array}{l}5.07^{* * * 6} \\
(0.74)\end{array}$ & $\begin{array}{l}4.53^{* * *} \\
(0.47)\end{array}$ \\
\hline $\mathrm{R}^{2}$ & 0.63 & 0.91 & 0.67 & 0.95 \\
\hline Akaike & 1921.4 & 909.0 & 1600.4 & 431.7 \\
\hline
\end{tabular}

The especially important fact is that the IE are the only subgroup of the subjects of small businesses where the amount of taxes shows the relation with the level of the tax rate not only in absolute terms, but also as a percentage of GRP (Table $\mathrm{V})$. This result seems to be the most reliable, because it is free of the influence of general economic trends on the dynamics of tax payments. In this regard, it is not surprising that the malleability of the TaxIpInGRP index at the tax rate is the lowest of all the equations considered in this research.

TABLE V. ESTIMATED COEFFICIENTS OF THE MODELS FOR IE USING THE STS

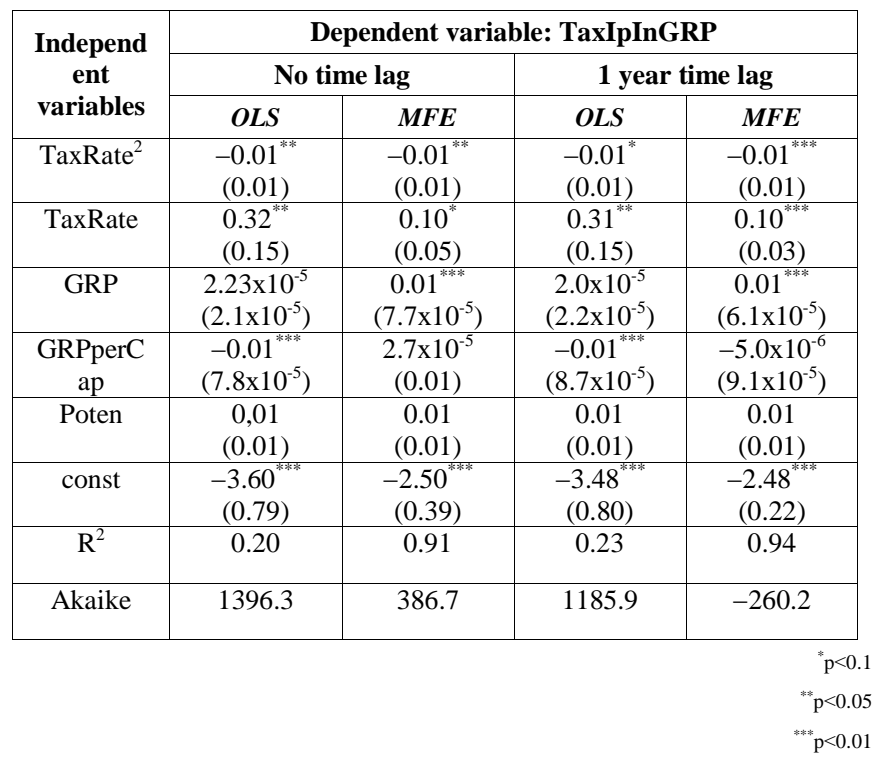

\section{The amount of the tax rate maximizing budget revenues}

By all means, one of the tasks of the state is to create the most favorable tax conditions for business development. However, the real interest of the authorities is to find a balance between promotion of entrepreneurship and collection of funds to finance budget expenditures. From this point of view, the confirmation of the quadratic relationship between the tax revenues and the tax rate for small businesses gives the possibility for calculating the optimal tax rate at which the value of the tax revenues of the state will be the largest.

On the basis of the obtained study results, we estimate the amount of such tax rates at the level of $9.7 \%$ for all the taxpayers using the STS in total. For SE, the optimal level of taxation is about $9.8 \%$, and for IE it is about $9.3 \%$. For the period from 2009 to 2015, when the territorial subjects of the Russian Federation were given authority to establish rates, the average amount of the rate on "net income" for the regions of the Russian Federation was $12.8 \%$, while the median value was $14.3 \%$. As of 2015 , the corresponding values were at the same level..

\section{CONCLUSION}

As a result of the study, the authors found out that the response of the Russian small businesses to changes in the corporate income tax rate is subjected to the consistent pattern described by the Laffer curve. On the basis of the dynamics of the total tax revenues according to the STS, it can be concluded that there is a parabolic dependence of the range of entrepreneurial activity on the size of the tax rate.

The change in the tax rate has a stronger impact on the IE business than the SE. The greater sensitivity of individual persons - entrepreneurs to the level of rates can be explained, as a rule, by the smaller size of production, which determines the high importance of external factors of economic activity, including fiscal ones. In addition, in the case of the IE the boundaries between legal and shadow parts of the economy are maximally mobile and transparent. Perhaps, the effect of the reduced tax rate for the IE is more evident than for the SE due to more active legalization of business.

The impact of the tax rate affects the dynamics of entrepreneurial activity in the year of its change and remains the same the next year. However, judging by the size of the derivative, the function of dependence of the amount of tax payments on the size of the tax rate with the annual time lag is changing slower than in the absence of the time lag. This consistent pattern is equally inherent in both SE and IE.

The maximum tax revenue from taxpayers using the STS is achieved at the rate on "net income" in the range of 9 to $10 \%$. And for IE this level is a little lower, than for SE. For regions that have a tax rate higher than the target value, it is advisable to make a decision on its reduction. The increase in the tax rate in the regions with the rate less than $9 \%$ will lead to increase in tax payments to the budget, but will adversely affect the development of small businesses. Differentiation of a tax rate for IE and SE using the STS can also contribute to increase in tax collections.

Thus, there is a significant potential for tax incentives for small businesses in Russia. Changes in tax rates can boost the development of small businesses and significantly increase their role in the economy of most Russian regions. The arrangement of favorable tax conditions due to the improvement of employment, production growth and tax 
deductions will lead to increase in competitiveness and stability of the dynamics of the regional economy. According to the results obtained by the authors, the regulation of the tax rate in the region has great potential as an effective tool of economic policy of the regional authorities aimed at achieving progress in the development of the territory.

\section{Acknowledgment}

The research was performed with financial support of RFBR within the research project №17-02-00153.

\section{References}

[1] J. Wanniski, "Taxes, revenues, and the "Laffer curve," The Public Interest, vol. 50, pp. 3-16, Winter 1978.
[2] A. Laffer, "The ellipse: an explication of the Laffer curve in a two factor model, “ in The financial analyst's guide to fiscal policy, V.A. Canto, C. W. Kadlec and A. B. Laffer, Eds. New York: Praeger, 1986, pp.1-35.

[3] J.M. Keynes, "The Means to Prosperity," London: Macmillan and Co, Limited, 1933, p. 37.

[4] J. Slemrod, L. Kawano, "How do corporate tax bases change when corporate tax rates change? With implications for the taxe rate elasticity of corporate tax revenues," International Tax and Public Finance, 2016, vol. 23, pp. 401-433.

[5] M. Devereux, "Developments in the taxation of corporate profit in the OECD since 1965: Rates, bases, and revenues," Working paper no. 07/04, 2007, Oxford University Centre of Business Taxation. [Electronic source]. URL: https://www.sbs.ox.ac.uk/sites/default/files/ Business_Taxation/Docs/Publications/Working_Papers/Series_07/WP07 04.pdf

[6] K. Clausing, "Corporate tax revenues in OECD countries," International Tax and Public Finance, 2007, vol. 14, iss. 2, pp. 115-133.

[7] A. Brill, K. Hassett, "Revenue-maximizing corporate income taxes: The Laffer curve in OECDcountries," American Enterprise Institute, Working paper no. 137, July 31, 2007, p. 19, www.aei.org/publication26577/ \# 22016 